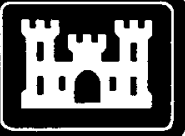

US Army Corps of Engineers

Waterways Experiment

Station

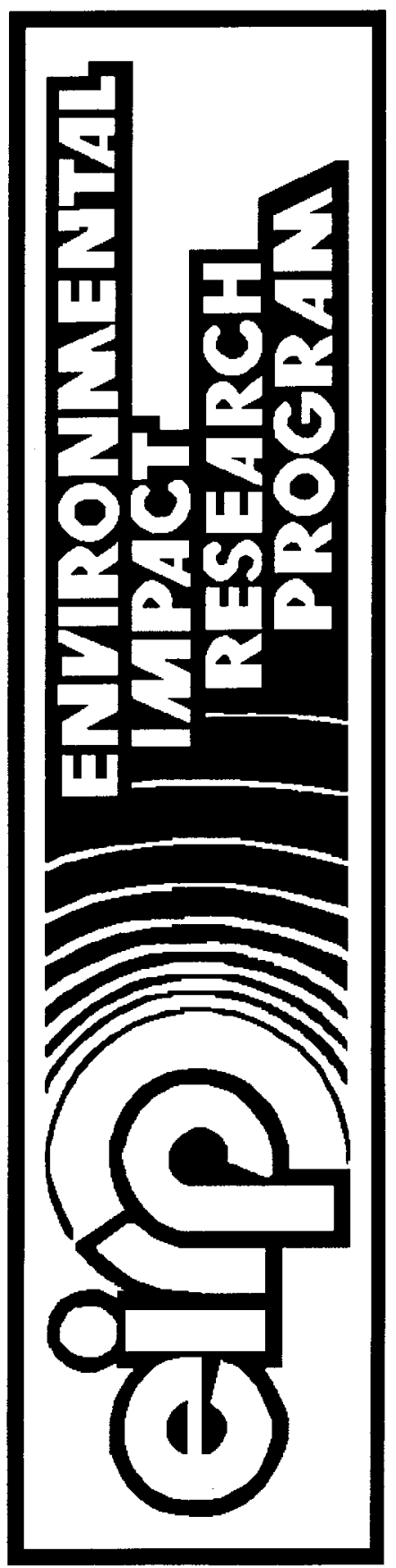

Information Bulletin

No. 96-1

May 1996

\section{North American sturgeon: Implications for the Corps of Engineers}

\author{
by K. Jack Killgore and Matthew D. Chan
}

Sturgeon are large, long-lived fishes that occur and spawn in most navigable rivers in the United States. Few groups of North American fishes have such an extensive range.

In North America, sturgeon represent nine taxa in two genera (Acipenser and Scaphirhynchus). Four of these taxa are listed as threatened or endangered under the Endangered Species Act.

Because sturgeon occur in main channels of rivers, they are vulnerable to the effects of flood control, navigation, and hydroelectric projects. For this reason, the U.S. Army Corps of Engineers has funded studies of sturgeon since the early 1980s. Section 7 of the Endangered Species Act directs the Corps to protect the species according to recommendations specified by the U.S. Fish and Wildlife Service. However, it is difficult to formulate management strategies with the limited life history information that is available on the species.

Protection and management of sturgeon has recently been recognized

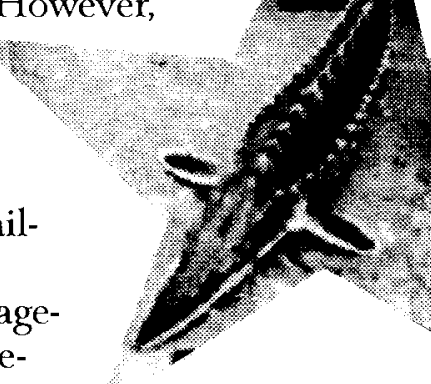

sturgeon issues related to Corps operations and maintenance activities, and summarizes current research priorities.

\section{Life history and ecology}

Sturgeon are primitive fishes that share a common and distinctive appearance-torpedo-shaped body; bony plates; long, hard snout; underslung mouth with barbels; and muscular upper lobe in tail (Figure 1). Some species grow to more than 4.5 meters in length and 450 kilograms in weight, and live as long as 100 years. Adults reach sexual maturity between

2 and 10 years of age and spawn intermittently every 2 to 5 years, depositing eggs in flowing water over gravel or rocks.

Sturgeon live on the bottom of large rivers or lakes, and can often be found in deep holes or flowing as a major environmental issue for the Corps. The issue was highlighted at the 1993 meeting of the Environmental Advisory Board in Portland, Oregon, and later at a sturgeon workshop conducted by the Corps' South Atlantic Division. A 3-year research unit to study sturgeon in the continental United States was begun in fiscal year 1995, as part of the Corps' Environmental Impact Research Program (EIRP).

This article presents life history information on the species, outlines water over sand

or gravel. All species are migratory, and some species are anadromous. Extensive migrations can occur, some exceeding 480 kilometers.

Typical seasonal movements include spring migrations of adults upstream to spawning grounds (from March to May); summer migration of juveniles and adults downstream to feeding and resting areas, where fish remain relatively inactive (June to September); fall migrations (September to November) of adults either downstream to overwinter, or upstream for fish that anticipate spawning the following spring. During migration, anadromous species may linger in reaches with salinities that facilitate osmoregulation. 


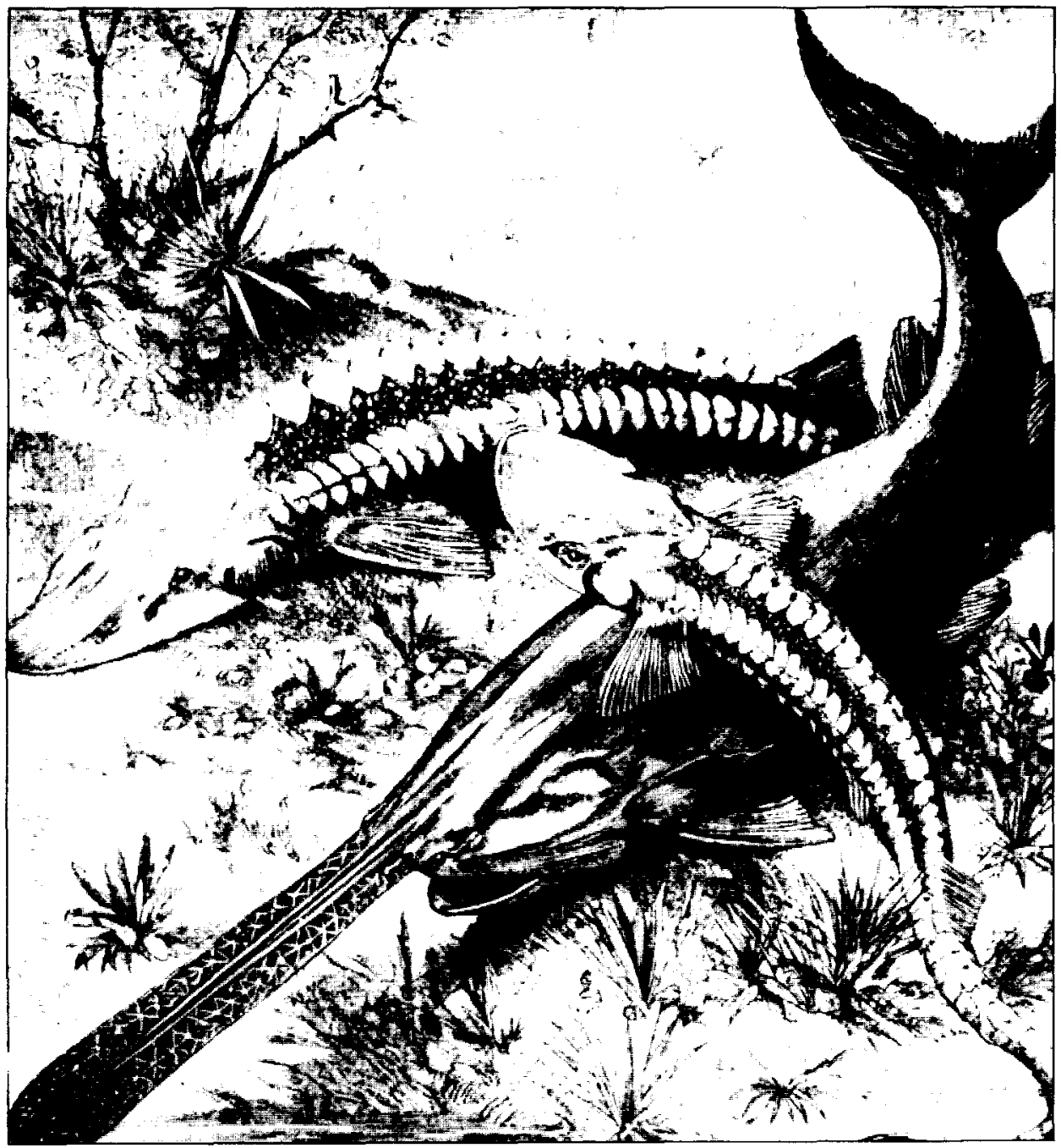

Figure 1. Sturgeon and paddlefish are closely, related and have skeletons composed mostly of cartilage. Fossils of these fish date to the Cretaceous Period (100 to 150 million years ago)

These reaches are termed "staging areas."

Sturgeon feed on a wide variety of aquatic animals. Juveniles consume small aquatic insects and crustaceans, particularly scuds, fly larvae, and maytly nymphs. Subadults and adults feed on molluscs, fish, and craytish.

\section{Taxonomy and status}

The genus Scaphirhynchus, which is native to North America, includes three sturgeon speciesshovelnose, pallid, and Alabama. The shovelnose sturgeon (S. platohynchus) occurs in fresh waters of the Mississippi River basin from western Pennsylvania to
Montana and south to Louisiana. Distribution of the pallid sturgeon ( $S$. albus) overlaps that of the shovelnose. The Alabama sturgeon (S. suttkusi) is endemic to the Mobile Bay drainage of

In the genus Acipenser, the Atlantic sturgeon ( $A$. oyyrinchus oxyrinchus) and the shortnose sturgeon (A. brevirostrum) are limited to Atlantic coastal drainages. The Gulf sturgeon (A.oxyrinchus desotoi) ranges from the Louisiana coast to central Florida. On the West Coast, two species of sturgeon occur: the white sturgeon (A. transmontanus) and the green sturgeon (A. medirostris). White sturgeon occur in coastal Alabama and Mississippi. rivers from Alaska south to Mexico, and landlocked populations exist in the upper Columbia River drainage, Montana, and possibly in Lake Shasta, California. Green sturgeon are usually found around the mouths of estuaries, ranging from the Gulf of Alaska southward to Mexico. Lake sturgeon (A. fulvescens) occur in fresh water, ranging from the Great Lakes and HudsonJames Bay to the Mississippi River basin.

Sturgeon were commercially important in the 19th and early 20th centuries for caviar, oil, and food. Indiscriminate harvesting led to rapid declines in their numbers. Their ability to recover from overharresting was hampered by their slow growth and a long period of sexual immaturity. Additional factors were the impacts from habitat alteration and the construction of dams, which prevented migration to spawning areas. Chamnel modifications associated with flood control, hydroelectric, and navigation projects mav also have impacted bottom riverine habitats used by sturgeon. The result is that most sturgeon are now uncommon throughout their ranges.

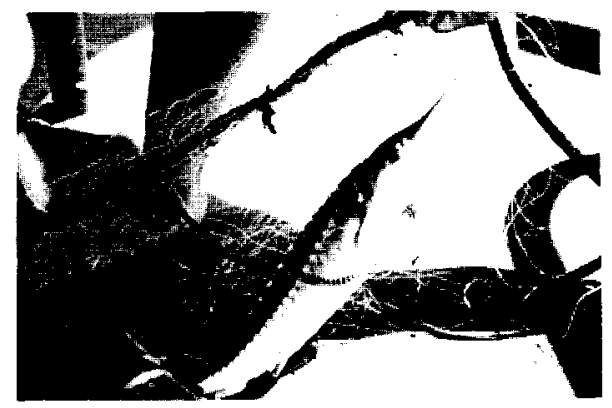

The distribution range of sturgeon includes most navigable rivers in the United States, and large portions of several Corps divisions (Figure 2). Federally threatened or endangered sturgeon species (Figure 3) are present in 10 Corps divisions. Two sturgeon species (shortnose and 


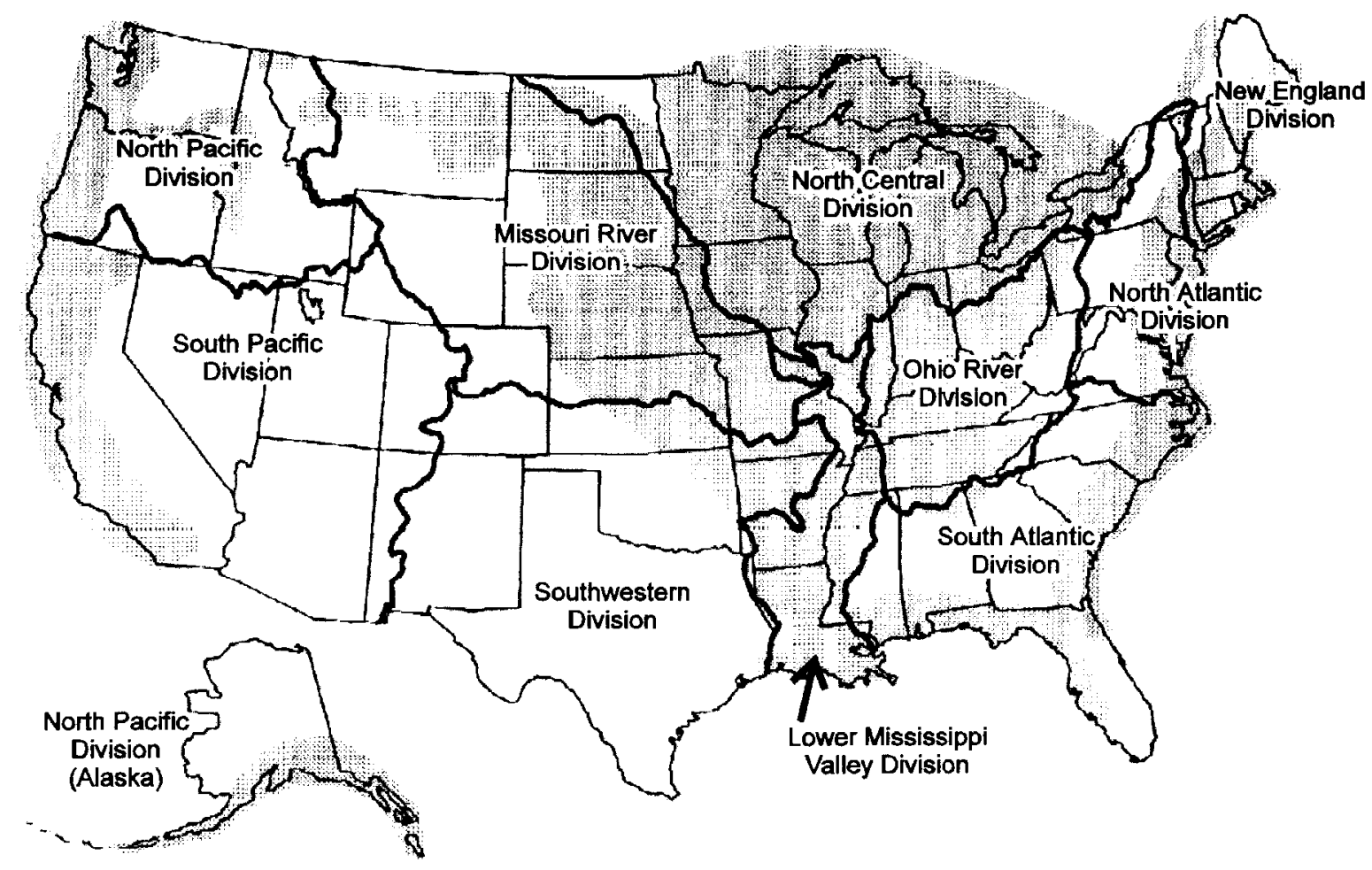

Figure 2. Distribution of sturgeon in Corps divisions

pallid) and one white sturgeon population (Kootenai River below Libby Dam, Montana) have been listed as endangered (Table 1). One subspecies (the Gulf sturgeon) has been Federally listed as threatened, and one species (Alabama sturgeon) is a species of special concern. All Federally listed sturgeon are also listed as endangered or threatened by at least two states, and some sturgeon are listed by all states within their respective ranges (Table 1 ).

\section{Corps of Engineers issues}

At least two navigation projects (Connecticut and West Pearl.rivers) have been temporarily delayed due to litigation because not enough is known about the life history of these fishes. To identify significant sturgeon issues, EIRP researchers contacted Corps division and district offices. A total of 36 individuals in 21 districts (representing 12 divisions) were asked to provide information on sturgeon species of interest, projects affected, expenditures, and related issues.

Because sturgeon have extensive ranges, the related issues cover large geographic areas and usually encompass several species with different ecological requirements. Lake, pallid, Gulf, white, shortnose, and green sturgeon were identified as species of concern. Sturgeon issues exist for most large navigable rivers in the United States.

The Corps' North Central, South Atlantic, Lower Mississippi Valley, New England, North Atlantic, Missouri River, and North Pacific divisions operate projects that are affected by the presence of threatened or endangered sturgeon. It is possible that the South Pacific Division might have problems in the $\mathrm{fu}^{-}$ ture with green sturgeon.

A concern that was voiced by most districts was insufficient information on spawning and rearing. Other project operational concerns included dredge entrainment, long-term habitat alteration by water control structures and dredging, barriers to migration caused by structures, and short-term habitat alteration from construction and maintenance. Entrainment and disturbance by barge traffic was identified as a future concern. With regard to planning projects, similar issues were noted, with barriers to migration most often cited.

The Corps offices were also asked to identify areas of research necessary to developing adequate protection and management plans.

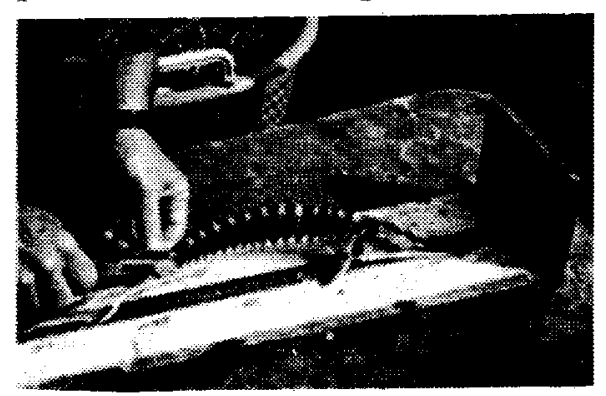




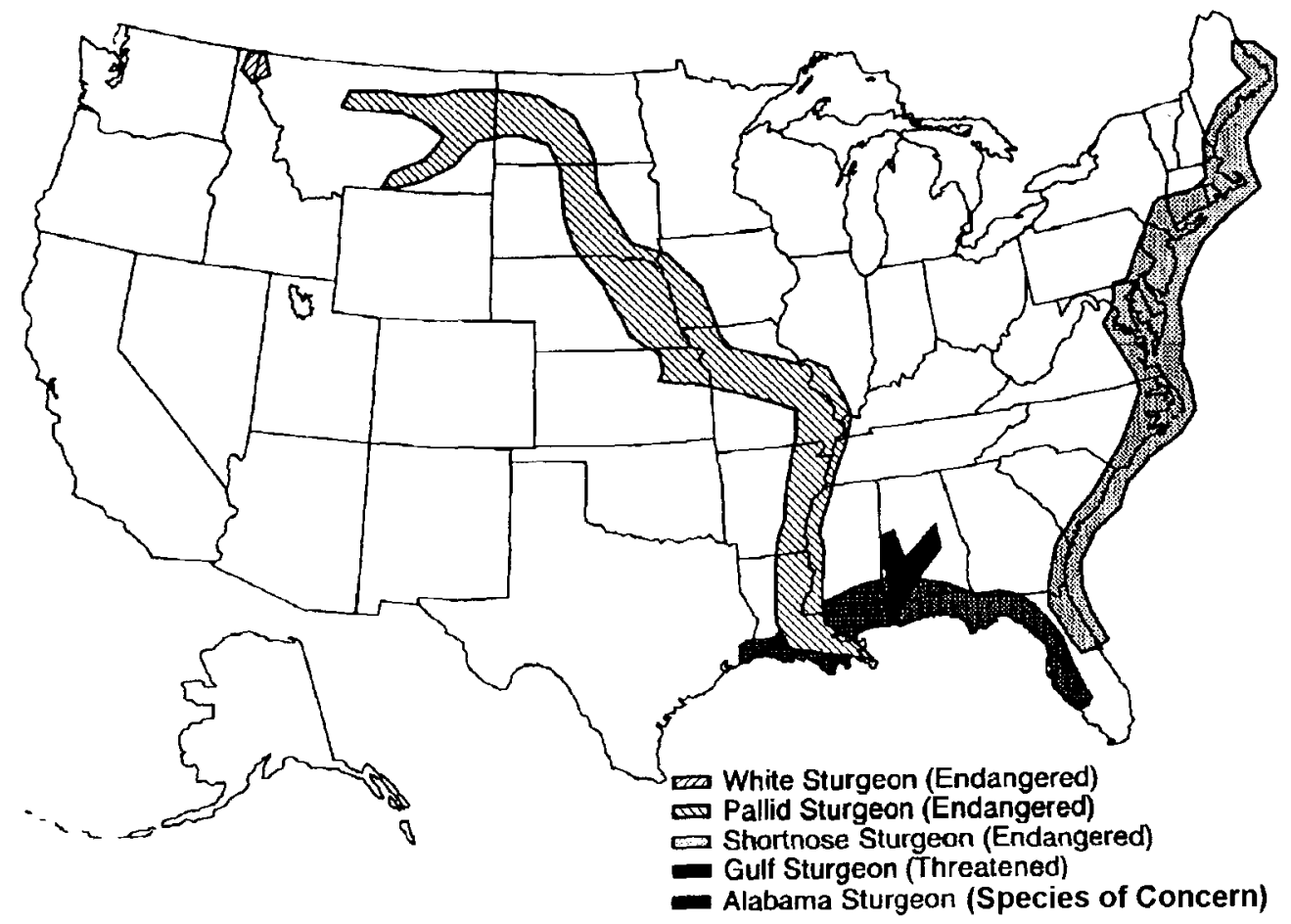

Figure 3. Distribution of Federally listed sturgeon in the United States

Table I. Status of North American Sturgeon

\section{Common Name}

(Scientific Name)

Shortnose sturgeon

(Acipenser brevirostrum)

Lake sturgeon

(A. fulvescens)

Gulf sturgeon

(A. oxyrinchus desotoi)

Atlantic sturgeon

(A. oxyrinchus oxyrinchus)

Green sturgeon

(A. medirostris)

White sturgeon

(A. transmontanus Kootenai River)

Pallid sturgeon

(Scaphirhynchus albus)

Shovelnose sturgeon

(S. platorynchus)

Alabama sturgeon

(S. suttkusi)
Federal Listing

Endangered

None

Threatened

None

None

Endangered

Endangered

None

Species of Concern
State Listings

Connecticut, Delaware, Florida, Georgia,

Maine, Maryland, Massachusetts,

New Hampshire, New Jersey, New York,

North Carolina, Pennsylvania,

South Carolina, Virginia

Illinois, Indiana, Iowa, Michigan, Missouri,

Nebraska, New York, Ohio, Pennsylvania,

Tennessee, Vermont

Florida, Louisiana, Mississippi

Connecticut, Massachusetts, Pennsylvania

None

Idaho, Montana

Arkansas, Illinois, Iowa, Kansas, Kentucky, Louisiana, Mississippi, Missouri, Nebraska, South Dakota, Tennessee

Texas

Mississippi 
These topics included distribution and movement, spawning habitat, swimming performance, and feeding habits of sturgeon.

Because of a lack of ecological and biological information on North American sturgeon, the most significant effects on Corps projects were increased expense and workload toward preparing environmental documents, conducting coordination activities, and monitoring field studies.

In response, the Corps districts have provided support, on a project-by-project basis, for collecting relevant information on sturgeon ecology and life history. In fiscal year 1994, approximately $\$ 778,000$ was spent on data gathering. Cumulative expenditures have totaled more than $\$ 1.8$ million.

Measures that have been implemented to avoid impacts to sturgeon during dredging include limiting the duration, using screens, and requiring observers on dredges to monitor potential impacts.

\section{Research priorities}

Despite the sturgeon research that has been conducted over the past 30 years, much information is lacking. Migration patterns, seasonal habitat requirements, feeding strategies, and most importantly, spawning and rearing behavior are still poorly documented for most species.

Generalizations about spawning habitat can be inferred from the few references that intensively addressed a certain species, but the timing and exact locations are speculative for most river systems. Larvae are rarely collected, so the habitat requirements of this early life history stage are unknown. Staging areas during adult migrations have not been identified in most rivers, and there is no information on habitat use by juvenile pallid, shovelnose, green, and Alabama sturgeon.

Telemetry can be an effective monitoring technique, but it cannot substantiate spawning. Sexes cannot be differentiated externally, and since adult sturgeon spawn intermittently, they may occur at spawning sites without releasing gametes. Furthermore, collecting fish and locating seasonal habitats in large river systems is difficult because

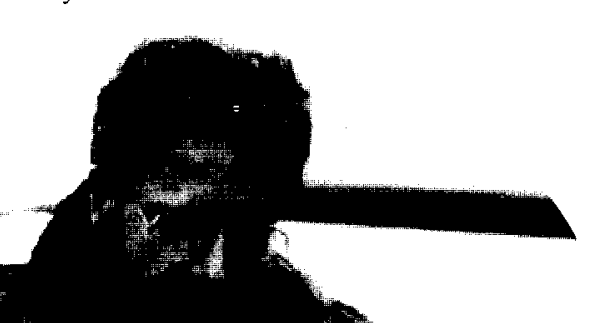

agencies to develop effective assessment and management techniques. Limited funding requires that managers prioritize the species based on the current effort (funding and number of individuals studying a species), status (Federal or state listing as threatened and endangered species), and geographic range.

For the Federally listed sturgeon species, the recommended priority for research is:

l. Pallid sturgeon. Although this species ranges throughout the Mississippi River drainage, few researchers are conducting field studies of it. Sampling efficiency is particularly difficult in the Mississippi River. Shovelnose sturgeon are closely related and relatively common in the Mississippi River. For experimental studies or habitat modeling, they could serve as surrogates for rare pallid sturgeon.

2. Gulf sturgeon. This species occurs in the Gulf coastal drainage from the Mississippi River to Florida. However, only a few rivers have been studied. Adults are infrequently collected, which suggests inadequate sampling or low recruitment.

\section{Shortnose and white} sturgeons. Numerous studies have been conducted on shortnose sturgeon, and this species continues to receive attention from universities and conservation groups. Only the Kootenai River population of white sturgeon was listed, representing a very limited range compared to other Federally listed species.

Current efforts under the EIRP work unit include field studies on Gulf sturgeon movement and habitat preference in the Pearl River and Lake 
Ponchartrain systems in Mississippi and Louisiana. Morphometric data are being collected on pallid and shovelnose sturgeon in the lower Mississippi River to improve field identification of these species and to evaluate possible hybridization. This work complements a previous study in the Missouri River. Commercial fishermen have assisted in these studies by collecting fish and identifying preferred habitats.

The behavioral ecology and swimming performance of recently spawned fish (obtained from hatcheries) are being evaluated in laboratory flumes. The results will help predict habitat preferences in rivers and the sturgeon's susceptibility to entrainment or barriers.

Research will also be conducted on techniques for collecting eggs and larvae, estimating population size from markrecapture, determining age and growth using fin rays or other suitable tissues, and developing innovative approaches for identifying the presence of sturgeon in deep, fast-flowing habitats.

Contacts with Russian scientists, who have been studying sturgeon for over a century, have been established. The information obtained through these contacts is expected to be useful in . designing monitoring studies.

\section{Information sources}

WES scientists reviewed the literature of the last 30 years on sturgeon biology, ecology, and management. A technical report summarizing this information, derived from more than 170 published studies, is scheduled for completion by September 1996 (Chan and Killgore, in preparation).

Several other sources of information on sturgeon are available. The "Second Summary of Sturgeon and Paddlefish Researchers and Managers" (Carmody 1994) identifies 273 researchers and managers interested in this topic. Interest for a particular sturgeon species was related to the area of

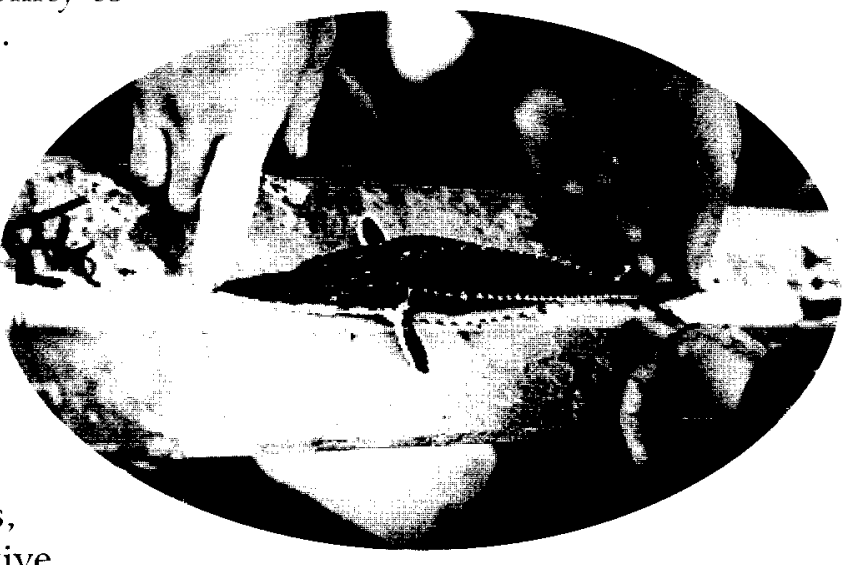

its range, relative abundance, and sport or commercial value. Consequently, lake sturgeon received the most interest, followed by shortnose, Atlantic, pallid, white, shovelnose, and Gulf sturgeon. The Alabama and green sturgeon had the least interest.
The Department of the Interior, the Department of Commerce (National Oceanic and Atmospheric Administration), and utility companies have been the principal funding sources for sturgeon studies.

The Sturgeon Quarterly, published by the Sturgeon Society, 1 includes studies from other countries. Sturgeon Notes, which focus on the shortnose and Atlantic sturgeon, are published by Cornell University ${ }^{2}$ under the sponsorship of the Hudson River Foundation.

Further information concerning the WES sturgeon studies is available from Dr. K. Jack Killgore, telephone (601) 634-3397, fax (601) 634-2398, or e-mail killgok@wes.army.mil.

\section{References}

Carmody, G. (1994). "Second summary of sturgeon and paddlefish researchers and managers," U.S. Fish and Wildlife Service, Panama City, FL. Chan, M. D., and Killgore, K. J. "North American sturgeon: Review of ecological literature and identification of research priorities," Technical Report (in preparation), U.S. Army Engineer Waterways Experiment Station, Vicksburg, MS.

I Available from The Sturgeon Society, 331 West 57 th Street, Suite 159 , New York, NY 10019.

2 Available from Department of Natural Resources, Fernow Hall, Cornell University, Ithaca, NY 14853-3001. 


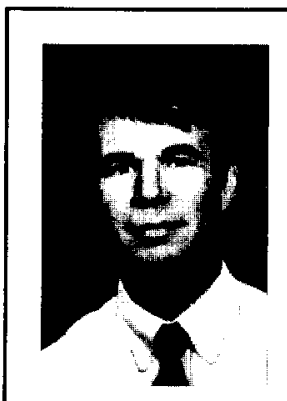

Dr. K. Jack Killgore is a research fishery biologist in the Environmental Laboratory. Waterways Experiment Station. II holds a B.A. degree in zoology from the University of Arkansas, an M.S. degree in fishery biology from Sam Houston State University, and a Ph.D. in fish ecology from the University of Mississippi. Killgore has been involped in research concerning fish ecology of lirrege river systems.
Matthew D. Chan holds a B.A. degree from Wittenberg University, Springfield, Ohio, and an M.S. degree in biologv from the University of Mississippi, Oxford. He works in the Aquatic Ecology Branch, Waterwaps Experiment Station. His professional interests include life history and beharioral ecology of lotic fishes and modeling inpulation dipnamics of fish species at the watershed level.

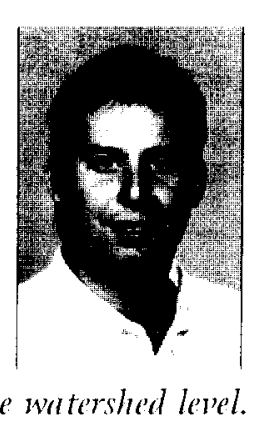

\section{Environmental Impact Research Program-Overview}

The Corps of Engineers' Environmental Impact Research Program (EIRP) is structured and managed to provide the Corps with a unique opportunity to investigate emerging problems in environmental areas as they relate to three research thrust areas. These areas focus on documenting and quantifying environmental effects associated with Corps activities; developing and demonstrating practical engineering and resource management strategies to minimize adverse effects of Corps activities and to protect and manage important natural and cultural resources; and developing, verifying, and demonstrating useroriented impact prediction and assessment techniques.

Traditionally, the strategy of the EIRP has been to provide rapid response to unexpected environmental research necds. It is the vehicle by which the Corps can initiate research in a wide variety of areas that are not covered by one of the specific $R \& D$ programs.

EIRP research has resulted in a number of practical and widely recognized products. Among these are the Corps' Wildlife Management Manual, the Site Restoration Manual, the Visual Assessment Manual, the Benthic
Resonrce Assessment Technique, and the Archeological Site Preserration Manual. Work on the Chesapeake Bay Model was initiated bv the EIRP. In addition, the EIRP has supported verification and testing of the Habitat Evaluation Procedure and vears of cooperative effort with the U.S. Fish and Wildlife Service. Practical field guidance has been developed on protection of endangered molluscs and the sturgeon, ecological effects of coastal structures and activities, and low- cost biotechnical erosion control techniques for shorelines and streambanks.

EIRP activities are conducted under the direction of Civil Works R\&D and Program Monitors at Headquarters, U.S. Army Corps of Engineers, with program management assigned to the U.S. Army Engineer Waterways Experiment Station. Continuous support and much-needed feedback is provided by the Field Review Group. A listing of key personnel is provided below.

\begin{tabular}{|lll|}
\hline & \multicolumn{1}{c}{ Office } & Telephone \\
\cline { 2 - 2 } Program Coordinator & & \\
Mr. Dave Mathis & CERD-C & \\
Program Monitors & & $(202) 761-1846$ \\
Ms. Cheryl Smith & CECW-PD & \\
Mr. Forester Einarsen & CECW-AO & $(202) 761-7029$ \\
Mr. Peter Juhle & CECW-EH-W & $(202) 761-0166$ \\
Program Management & & \\
Dr. Russell I: Theriot & CEWES-EP-W & $(601) 634-2733$ \\
Mr. Robert Lazor & CEWES-EP-W & $(601) 634-2935$ \\
Field Review Group & & \\
Mr. Coleman Long & & \\
Ms. Beverley Gretzen & CESAW-EP-PE & $(910) 251-4745$ \\
Mr. Marty Hathorn & CESPD-PD-R & $(415) 705-1560$ \\
Dr. Tom Pullen & CESWF-PL-R & $(817) 334-2095$ \\
Mr. Peter Doukas & CELMV-E'T-PR & $(601) 634-5851$ \\
Mr. James Reese & CENAD-ET-P & $(212) 264-7814$ \\
Mr. Doug Latka & CENPD-ET-PR & $(503) 326-3832$ \\
Ms. Carroll Kleinhans & CEMRD-ET-P & $(402) 697-2477$ \\
& CENCD-PE-PD-ER & $(312) 886-5469$ \\
\hline
\end{tabular}




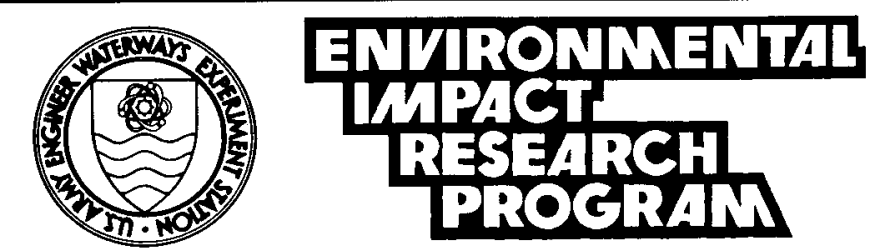

This bulletin is published in accordance with AR 25-30 as an information exchange function of the Corps of Engineers. Its purpose is to disseminate research results on emerging problems addressed by the Corps' Environmental Impact Research Program. The contents of this bulletin are not to be used for advertising, publication, or promotional purposes nor are they to be published without proper credit. Citation of trade names does not const itute an official endorsement or approval of the use of such commencial products. Communications are welcomed and should be directed to Dr. Russell F. Theriot, U.S. Army Engineer Waterways Experiment Station, ATTN: CEWES-EP-W, 3909 Halls Ferry Road, Vicksburg, MS 39180-6199; telephone (601) $634-2733$.

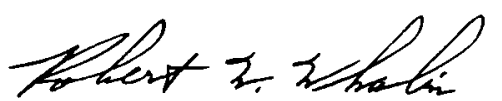
ROBERT W. WHALIN, PhD, PE Director

\author{
$M-d \exists-S \exists M \exists O$ \\ SS \\ 66เ9-08เ6e IddISSISSIW ' \\ a $\forall O Y$ 人

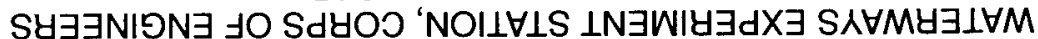 \\ $\wedge W \forall \forall \exists H \perp \exists O \perp N \exists W \perp \forall \forall d \exists a$
}

